\title{
The Needs of Interactive Electronic School Books to Enhance the Critical Thinking Skills of the Students
}

\author{
Febriana Andita Pradana ${ }^{1}$, Agus Suyatna ${ }^{1}$ \\ ${ }^{1}$ University of Lampung Jl. Soemantri Brojonegoro 1 Bandar Lampung, 35145, \\ INDONESIA. \\ E-mail: anditaana@gmail.com
}

\begin{abstract}
Physics electronic school books (BSEF) that are currently used in the schools are static and have not optimized its digital format. The purpose of this research is to produce a dynamic and interactive BSEF design that can be used for self-study, designed with scientific approach, and can foster students' critical thinking skill. The method used in this study is research and development which is until to design validation test. The sample for requirement test consisted of 130 high school students and 4 physics teachers drawn randomly from 3 different Senior High Schools in Lampung Province. The data of BSEF needs are collected using questionnaires and analyzed using quantitative descriptive.The expertise design test is carried out by experts in the field of physicseducation. The expertise instrument test in the form of interactive BSEF design assessment sheet. Based on research data, it is known that students and teachers want an interactive BSE that can be used independently, prepared with scientific approach, can enhance the critical thinking skills and contains the interactive exercises equipped with feedback. The results of the expertise test show that interactive BSE that start the showing a physics phenomenon which increases curiosity, is based on scientific approach stages, and contains experimental simulations and exercises which are supported with feedback.
\end{abstract}

Keywords: critical thinking; interactive electronic books; self-study

\section{INTRODUCTION}

The current curriculum demands are emphasized with 21st-century skills, which students need to succeed in the future. One of the basic demands on 21st-century skills is that students have critical thinking skills [1]. The success of the curriculum is not only determined by the design, but more important is the implementation of learning implementation facilitated by learning resources and adequate learning methods. Lack of student involvement in learning because students have only been required to memorize 
the subject matter rather than understand, analyze a problem, and solve a problem that may be encountered in everyday life, so the critical way of thinking is poorly trained [2].

The book is one of the learning resources used by $90 \%$ of students. The physics books used today are less than expected and are used only as guides, references or sources of information in physics learning. Electronic physics school books (BSEF) used in schools today are static and have not optimized the digital format it has. To overcome the limited available face-to-face learning time, BSEF should be able to be used independently by students and reduce their difficulty in understanding abstract physics material especially on the topic of quantum phenomena.

Virtual technology is defined as a simulation or visualization that represents an abstract scientific phenomenon. Virtual technology offers an innovative approach to using virtual science labs by incorporating all the components of laboratory activities to provide improved learning experience [3]. Learning activities with experimental methods take a long time. In the even semester of the class XII students have limited time to learn, so that learning activities are only dominated by teachers who only use lecture methods to convey material that is considered important [4], ignore the scientific approach to learning activities, $72 \%$ of students find it difficult to understand the material and lack of trust Self in the face of the test.

Quantum phenomena is a very microscopic topic and can not be observed directly and require a high level of understanding [5]. High-level understanding can be achieved by implementing a scientific-based learning approach that involves observation or observation activities required for the formulation of hypotheses or collecting data. Scientific methods are generally based on the exposure of data obtained by observation or experiment [6]. Therefore, experimental activities may be replaced by the activity of obtaining information from various sources [7].

Critical thinking skills can be grown through a series of learning activities. In learning activities students are required to learn actively and independently. Critical thinking skills can be trained by providing practice questions equipped with feedback. The exercise of the given problem must be analytical, so as to train and improve students' critical thinking skills. The purpose of this research is to produce BSEF design of dynamic and interactive quantum phenomena which can be used for self-study, designed with scientific approach, and can grow students' critical thinking skill.

\section{METHODS}

The method used in this research is BSEF design development research with ADDIE model with stages (1) analyze, (2) design, (3) development, (4) implementation and (5) evaluation. Research development is limited to the development stage.

The first stage is the analysis that becomes the basis for determining the development needs of BSEF design of quantum phenomena. Activity analysis includes needs analysis and analysis of learning materials at school. The instrument used in this analysis phase is a questionnaire given to 130 high school students and 4 physics 
teachers drawn at random from 3 different senior high schools in Lampung Province to determine the required BSEF criteria.

In the design phase, the design of BSEF quantum phenomena with scientific approach encompasses the breadth and depth of the material so that it can measure students' critical thinking skills and be able to train students to learn independently. At the development stage, the preparation of the BSEF component is considered appropriate to the needs of learning activities in schools. Besides, BSEF also validates the design of quantumphenomena by experts in the field of physics education, using validation instrument in the form of BSEF design assessment sheet. The data collected is then analyzed in descriptive quantitative terms.

\section{RESULT AND DISCUSSION}

Based on the analysis of the needs of teachers and students expect a change in the implementation of learning, where students can be active in learning activities, not only hear the explanation submitted by the teacher. Many activities can be done to make students active in learning activities, including providing other learning resources, conducting experiments, and using various learning media (Table I). Technological advances have the potential to transform learning activities by engaging students in innovative exploration learning activities. In addition to changing the style of learning, technology allows for innovation in learning [8].Electronic books are the result of technological advances used as portable reading devices, with certain file formats to provide ease of access and use [9,10]. In addition to being a reading resource, an appropriately designed booklet allows users to access, store and share information in a short period of time [11,12] and integrate it into other learning resources and media, such as a practicum simulation.

TABLE I. STUDENT EXPECTATIONS IN LEARNING ACTIVITIES

\begin{tabular}{clc}
\hline No. & \multicolumn{1}{c}{ Component } & Percentage \\
\hline 1 & BSE & \\
& a. Contains a description of the material with a video showing the & $54 \%$ \\
& phenomenon & \\
b. Loading interactive question exercises equipped with feedback & $63 \%$ \\
c. Loading simulations that can be used independently & $12 \%$ \\
\hline 2. & Instructional Method & $82 \%$ \\
a. Experiment & $68 \%$ \\
b. Demonstration & $46 \%$ \\
c. Exercises & $73 \%$ \\
\hline Instructional Media & $34 \%$ \\
a. Live Experiments & $32 \%$ \\
b. Virtual Laboratory & \\
c. Tutorial video &
\end{tabular}




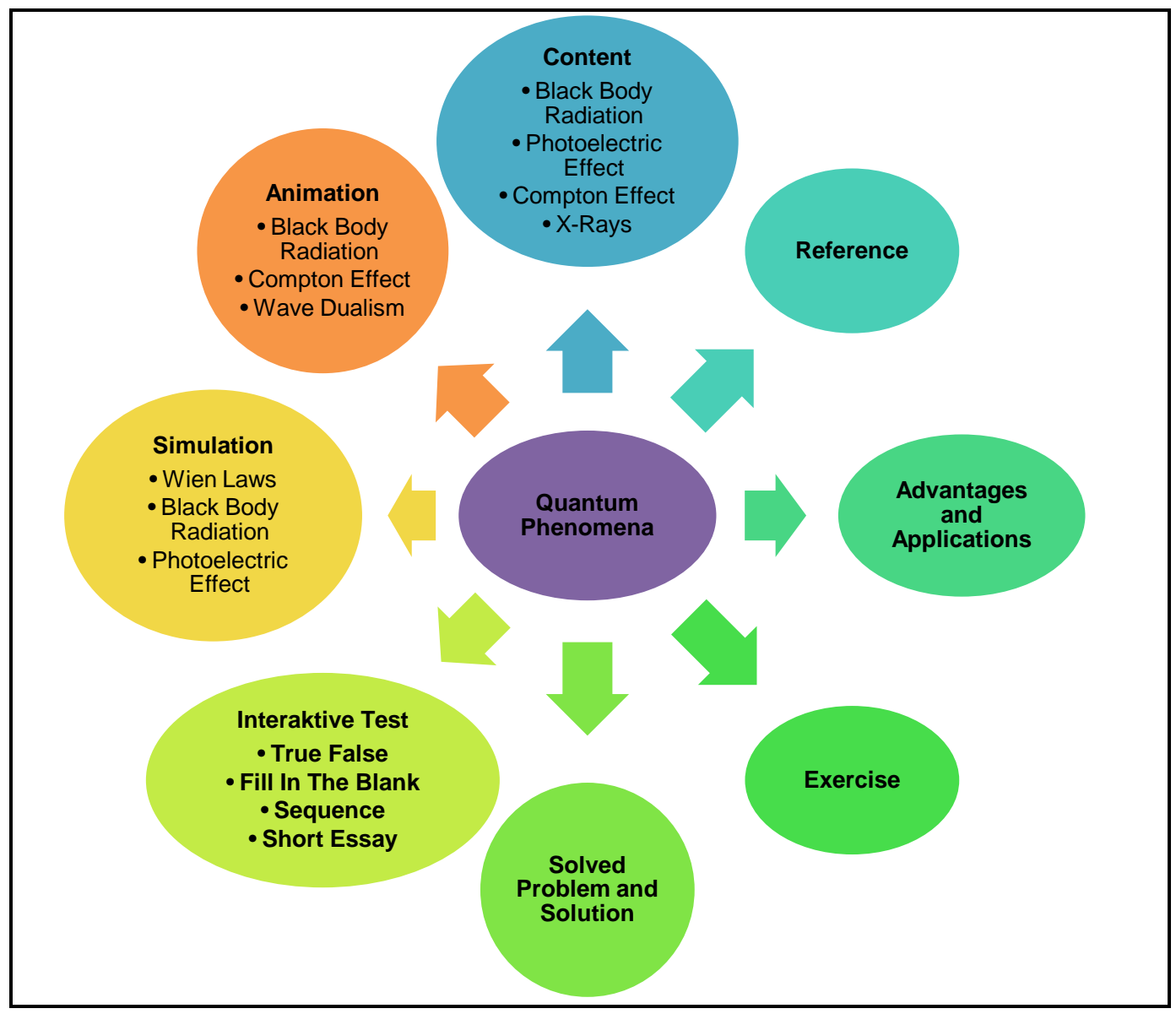

Figure 1. BSEF Content Design Quantum Phenomena

Based on the results of validation of experts obtained BSEF design contents Quantum Phenomena (Figure 1), including description material, animation, simulation, sample problems and discussion, assignments, benefits and applications, references or other learning resources equipped with interactive tests [13]. The description of the material of quantum phenomena begins with the failure of classical physics in explaining microscopic material studies as described in Stefan-Boltzmann's Law, the Law of Wien Shift, and Rayleigh-Jeans Law, thus turning to modern studies initiated by the Quantum Plank Hypothesis. The photoelectric effect, Compton effect, and X-ray effects will also be described. In addition to using the material description, students will more easily understand the material if supported by graphics, images, animations, and simulations [14].

The use of virtual technology can help students acquire relevant knowledge and at the same time be able to add ideas through the visualization of unobserved phenomena directly. An animation is a graphic art that can be used to simulate motion that can be seen in a certain time [15]. Based on BSEF component requirement analysis data (Table II), the animation component is indispensable in BSEF quantum phenomena 
material. Animations to be contained in the BSEF for Black Metal Radiation will show the black body phenomenon can absorb all the coming electromagnetic radiation so that no radiation is reflected or reflected back, the colored lights inflicted on the object being heated can indicate the occurrence of electromagnetic radiation. In Compton effect material is given an animation of the course of photons that pound an electron in a plate, which resulted in the occurrence of scattering. While the material of wave dualism given animation can illustrate that light can be as particle and wave.

Simulation and animation are examples of the application of virtual technology, which has only been regarded as a learning medium, can be used to improve students' understanding of a material and help students develop explanations of complex material [16]. Virtual technology using a virtual laboratory can incorporate all components of laboratory activity through observed phenomena to improve student physics learning outcomes as well as provide enhanced learning experience $[17,18]$. The practicum simulations contained in the BSEF include a photoelectric practicum simulation to determine the threshold frequency and kinetic energy generated for each metal, otherwise it will contain a black-body radiation practicum simulation to see the amount of radiated energy emitted. Based on expert validation, the validator also expects the simulation of practicum for the material of Wien spinning law which can be made in graph of frequency function and wavelength.

The need for active, interesting and fun learning activities encourages the use of varied media and learning resources [19,20]. Learning activities with varied media and learning resources can provide a lot of information clearly so as to deepen students' understanding [21]. Understanding students in a learning material can be measured using various forms of interactive tests.Based on expert validation, the type of interactive test that is considered very appropriate in BSEF is the type of matter of true/false, fill in the blank, sequence, and short essay. The use of interactive tests can train students' critical thinking skills, support effective feedback practices and enable students to take control of learning and assess their own learning outcomes.

TABLE II. BSEF COMPONENT NEEDS ANALYSIS QUANTUM PHENOMENA

\begin{tabular}{|c|c|c|c|}
\hline No. & BSEF Components & $\begin{array}{c}\text { Average } \\
\text { Score }\end{array}$ & Suggestion \\
\hline \multirow[t]{5}{*}{1} & Learning materials & & \\
\hline & $\begin{array}{l}\text { Black Body Radiation } \\
\text { a. Stefan-Boltzmann Law } \\
\text { b. Law of Wien Shift } \\
\text { c. Rayleigh-Jeans Law } \\
\text { d. Quantum Planck }\end{array}$ & $\begin{array}{l}3.33 \\
3.33 \\
3.00 \\
3.67 \\
3.33\end{array}$ & \multirow{4}{*}{$\begin{array}{l}\text { a. Emphasizes the material shift } \\
\text { between classical physics's } \\
\text { failure to discuss microscopic } \\
\text { material leading to modern } \\
\text { physics studies } \\
\text { b. Displays a graph of the } \\
\text { relationship between Stefan- } \\
\text { Boltzmann's Law, the Law of } \\
\text { Wien Shift, and Rayleigh-Jeans } \\
\text { Law }\end{array}$} \\
\hline & Photoelectric Effect & 3.33 & \\
\hline & $\begin{array}{l}\text { Compton effect } \\
\text { a. Hypothesis de Broglie } \\
\text { b. Heisenberg Uncertainty Principle }\end{array}$ & $\begin{array}{l}3.33 \\
3.33 \\
3.33\end{array}$ & \\
\hline & X-ray & 3.67 & \\
\hline \multirow[t]{2}{*}{2} & Animation & & \\
\hline & $\begin{array}{l}\text { Black Body Radiation } \\
\text { a. Radiation emission entering the enclosed space } \\
\text { can not get out again } \\
\text { b. Discoloration on metal when given continuously } \\
\text { heat }\end{array}$ & $\begin{array}{l}3.67 \\
3.67\end{array}$ & $\begin{array}{l}\text { Provide animations that are } \\
\text { considered appropriate to the } \\
\text { material that will be out on the } \\
\text { exam. }\end{array}$ \\
\hline
\end{tabular}




\begin{tabular}{|c|c|c|c|}
\hline \multicolumn{4}{|c|}{ TABLE II. cont. } \\
\hline & $\begin{array}{l}\text { c. Heat generated from the emission of } \\
\text { electromagnetic waves in the heating device }\end{array}$ & 3.67 & \\
\hline & Compton effect & 3.33 & \\
\hline & Waves de Broglie & 3.33 & \\
\hline \multirow[t]{3}{*}{3} & Practical Simulation & & \\
\hline & $\begin{array}{l}\text { Black Body Radiation (Determining the } \\
\text { Wavelength and Intensity of Radiation that is } \\
\text { affected by the surface temperature) }\end{array}$ & 3.33 & \multirow{2}{*}{$\begin{array}{l}\text { Need to add a practical simulation } \\
\text { for the Law of Wien Shift, so that } \\
\text { students are able to find the } \\
\text { relationship between frequency } \\
\text { function and wavelength function to } \\
\text { temperature. }\end{array}$} \\
\hline & $\begin{array}{l}\text { Photoelectric } \quad \text { Effect } \quad \text { (Determining threshold } \\
\text { frequency and kinetic energy for each metal) }\end{array}$ & 3.33 & \\
\hline 4 & Summary & 3.67 & $\begin{array}{l}\text { In the summary of the material } \\
\text { should be added the benefits and } \\
\text { application of the material } \\
\text { phenomena of kuantu } m \text { in } \\
\text { berkembangan technology }\end{array}$ \\
\hline 5 & Solved Problem adn Solution & 4.00 & \multirow{2}{*}{$\begin{array}{l}\text { Needs to be given for each sub of } \\
\text { the displayed material }\end{array}$} \\
\hline 6 & Exercise & 3.67 & \\
\hline \multirow[t]{8}{*}{7} & Interactive Test & & \\
\hline & True / False & 3.00 & \multirow{7}{*}{$\begin{array}{l}\text { Adjust the interactive test form to } \\
\text { the characteristics of each material }\end{array}$} \\
\hline & Multiple Choice & 3.00 & \\
\hline & Multiple Response & 3.00 & \\
\hline & Fill in the Blank & 3.50 & \\
\hline & Matching & 3.00 & \\
\hline & Sequence & 3.50 & \\
\hline & Short Essay & 3.50 & \\
\hline
\end{tabular}

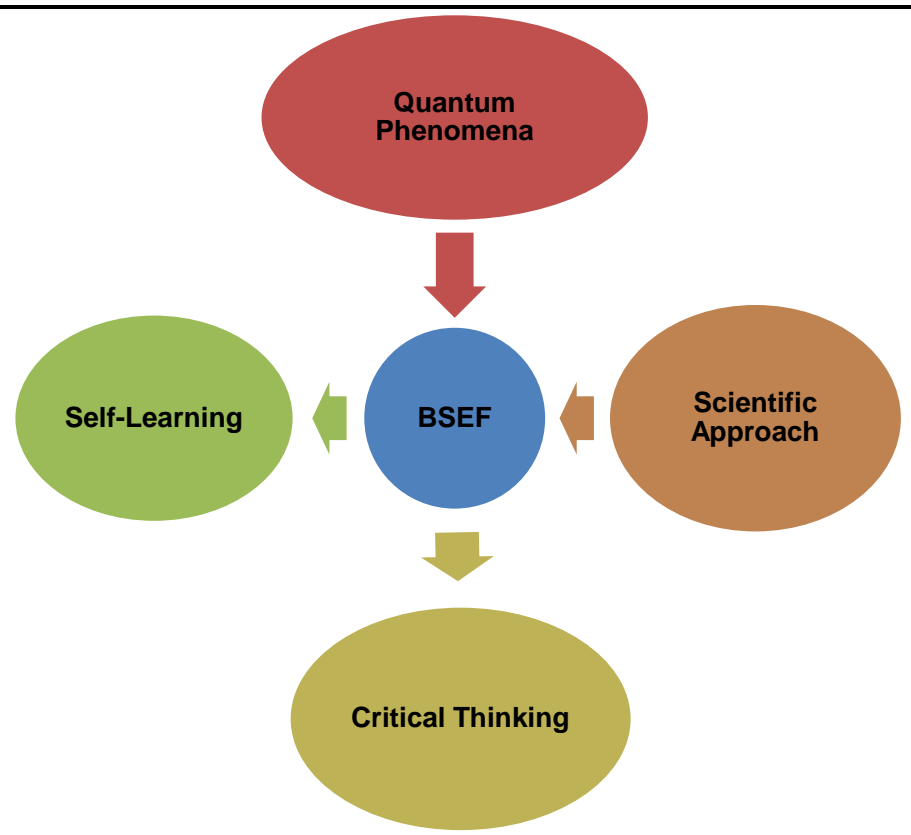

Figure 2. BSEF Design of Quantum Phenomena

BSEF quantum phenomena developed with a scientific approach can be used to improve critical thinking skills and students' self-learning abilities (Figure 2).The 
interactive BSEF is designed to have a navigation button that provides the flexibility to select teaching materials and learning resources, beginning with a phenomenon of physics that cultivates curiosity, organized on the basis of scientific approach stages, containing experimental simulations and exercise questions with feedback.

The use of technology can improve learning outcomes that support improvements in students' critical thinking skills. Critical thinking skills can be established when students carry out investigative tasks [22, 23]. Possible tasks to train students' critical thinking skills include exercising an analytical matter in which students are still required to collect their duties to the teacher by e-mail at a certain time. The concept of critical thinking can be seen as a way of thinking that develops from collecting some skills [24]. Critical thinking skills involve aspects of the accuracy and ambiguity of the information provided, including the ability to evaluate arguments based on specific criteria and evidence [25].

The development of critical thinking skills is very important [26] and relies on learning activities in the classroom where the emphasis is on the transmission of knowledge [27]. Critical thinking skills can be observed by asking students to answer clarification questions, considering source credibility, making inductions and considering induced results, defining terms, and defining alternatives for solving specific problems [28].

\section{CONCLUSION}

Based on the analysis results obtained BSEF quantum phenomena design that can be used as a source of independent learning, has a navigation button that provides the flexibility to select teaching materials and learning resources, starting with a phenomenon showing a curiosity phenomenon, prepared based on stages of scientific approach, and loading learning materials, animation, simulation, sample questions and discussion, and practice questions to hone students' critical thinking skills equipped with feedback.

\section{REFERENCES}

[1] Ibrahim, Muslimin. 2014. Pembelajaran Sains di Sekolah Dasar Berbasis Kurikulum 2013. Premiere Educandum. 4 (1): 1-9.

[2] Insyasiska, Dewi. Siti Zubaidah, Herawati Susilo. 2015. Pengaruh Project Based Learning Terhadap Motivasi Belajar, Kreativitas, Kemampuan Berpikir Kritis, dan Kemampuan Kognitif Siswa pada Pembelajaran Biologi. Jurnal Pendidikan Biologi. 7(1): 9-21.

[3] Lindgren, R., \& Johnson-Glenberg, M. 2013. Emboldened By Embodiment: Six Precepts for Research on Embodied Learning And Mixed Reality. Educational Researcher, 42(8): 445-452.

[4] Gani, Abdul, Rini Safitri, Habibati, Nurul Fajri Saminan. 2016. The Study of High School Students Scientific Attitudes on Learning Heat and Temperature with Cooperative Inquiry Labs Model. Proceeding the 1st International Conference on Teacher and Training Education Sebelas Maret University.1 (1): 279-283. 
[5] Abdurrahman, Liliaasari, A. Rusli, Bruce Waldrip. 2011. Implementasi Pembelajaran Berbasis Multi Representasi untuk Peningkatan Penguasaan Konsep Fisika Kuantum. Cakrawala Pendidikan. (1):30-45.

[6] Karacop, Ataman, Emine H Diken. 2017. The Effects of Jigsaw Technique on Coorperative Learning on Prospective Science Teachers Science Process Skill. Journal of Education and Practice. 8 (6): 86-97.

[7] Sani, Ridwan Abdullah. 2014. Pembelajaran Saintifik untuk Implementasi Kurikulum 2013. Jakarta: Bumi Aksara.

[8] Haryanto, H U Kaltsum. 2016. E-Learning Program Adoption: Technology Acceptance Model Approach. Proceeding the 2nd International Conference on Teacher and Training Education Sebelas Maret University. 2 (1): 616-622.

[9] Walters, W. H. 2013. E-books in academic libraries: challenges for sharing and use. Journal of Librarianship and Information Science, 46(2), 85-95.

[10] Girard, Adam. 2014. Reader's block: a systematic review of barriers to adoption, access and use in ebook user studies. Information Research. 19 (2).

[11] Ferit, K. Jaroslaw K. 2015. Ethnical Issues of ICT Use by Teacher Trainers: Use of E-book in Academic Settings. Journal of Faculty of Educational Sciences. 48 (2): 83-102.

[12] Solcova, Lucia. 2016. Interactive Textbook- A New Tool in Off-Line and On-Line Education. The Turkish Online of Educational Technology. 15 (3): 111-125.

[13] Azmi, Nurul, Dwi Maryono, Rosihan A Y. 2016. Android Based Application for Supporting English for Disability. Proceeding the 2nd International Conference on Teacher and Training Education Sebelas Maret University. 2 (1): 194-201.

[14] Lai, Ching-San. 2016. Integrating E-books into Science Teaching by Preservice Elementary

[15] School Teacher. Journal of Education in Science, Environment and Health. 2 (1): 57-65.

[16] Chandra, H.2002.MembuatSendiriAnimasiProfesionaldengan 3ds max 4.2. Jakarta: Elex Media Komputindo.

[17] Chiu, J. L., \& Linn, M. C. 2014. Supporting Knowledge Integra-tion In Chemistry With A VisualizationEnhanced Inquiry Unit. Journal of Science Education and Technology, 23(1): 37-58.

[18] Chiu, Jennifer L., Crystal J Dejagher. Jie Chao. 2015. The Effects of Augmented Virtual Science Laboratories on Middle School Understanding of Gas Properties. Computer and Education. 85: 59-73.

[19] Mulyanto, R Ani. 2016. Developing Learning Media of the Projection Drawing to Improve the Quality of Learning Process and Outcomes. Proceeding the 1st International Conference on Teacher and Training Education Sebelas Maret University.1 (1): 427-434.

[20] Marsono. Mingchang Wu. 2016. Designing a Digital Multimedia Interactive Book for Industrial Metrology Measurement Learning. I.J. Modern Education and Computer Science. (5): 39-46.

[21] Yusuf, Irfan, S W Widyaningsih, D Purwati. 2015. Pengembangan Perangkat Pembelajaran Fisika Modern Berbasis Media Laboratorium Virtual Berdasarkan Paradigma Pembelajaran Abad 21 dan Kurikulum 2013. Pancaran. 4 (2): 189-200.

[22] Leow, Fui-Theng. Mai Neo. 2014. Interactive Multimedia Learning: Innovating Classroom Education In a Malaysian University. The Turkish Online Journal of Educational Technology. 13 (2): 99-110.

[23] Anam Hadi Saputra, Zainal., Leny Yuanita, Muslimin Ibrahim. 2016. Pengembangan Perangkat Pembelajaran Kimia Model Inkuiri untuk Meningkatkan Penguasaan Konsep dan Melatih Keterampilan Berpikir Kritis Siswa SMA. Jurnal Pendidikan Sains Pascasarjana Universitas Negeri Surabaya. 6(1): 1218-1223.

[24] Sinaga, Parlindungan, Shelly Feranie. 2017. Enchancing Critical Thinking Skills and Writing Skills through the Variation in Non-Traditional Writting Task. International Kournal of Instruction. 10 (2): 6984.

[25] Al-Osaimi, K.H., Reid, N., and Rodrigues, S. 2014. Critical Thinking - Can it be Measured? Journal of Science Education, 15(1), 30-36.

[26] Khan, S. I. 2017. Critical thinking in a higher education functional English course. European Journal of Educational Research, 6(1), 59-67.

[27] Al-Osaimi, K.H., Reid, N., and Rodrigues, S. 2015. Critical Thinking - Can it be Developed? Journal of Science Education, 15(2), 57-75.

[28] Akbar, R. A., Akhtar, M., Hussain, A., and Abiodullah, M. 2013. Beliefs and Practices of Teacher Educators Teaching B.Ed (Hons) and ADE in Universities and Affiliated Colleges in Punjab, a paper 
presented at the Education Conference on Teacher Recruitment, Preparation, and Policy held at University of Karachi, Pakistan on August 20-21, 2013.

[29] Surayya L, I W. Subagia, I N. Tika. 2014. Pengaruh Model Pembelajaran Think Pair Share Terhadap Hasil Belajar IPA Ditinjau Dari Keterampilan Berpikir Kritis Siswa. e-Journal Program Pascasarjana Universitas Pendidikan Ganesha. 4: 1-11. 